scresned By SINAI Journal of Applied Sciences

\title{
EFFECT OF SOIL APPLICATION WITH NITROGEN LEVELS AND POTASSIUM SILICATE FOLIAR SPRAY ON GROWTH AND YIELD OF BLACK CUMIN (Nigella sativa L.)
}

\author{
Asmaa S.I. El-Leithy ${ }^{*}$, Sonia A.S. Abdallah ${ }^{1}$ and M.A.M. Ali ${ }^{1}$ \\ 1. Dept. Plant Prod., Fac. Environ. Agric. Sci., Arish Univ., Egypt.
}

\begin{abstract}
This study was carried out during the winter seasons of 2014-15 and 2015-16 at the Experimental Farm of Environmental Agricultural Sciences Faculty, Arish University, North Sinai Governorate, Egypt. The main effects and their interactions of four different nitrogen levels $(0,50,75$ and or $\mathrm{Kg} / \mathrm{fed})$ and four foliar application rates of potassium silicate spray $(0$, 4,6 or $8 \mathrm{~cm}^{3} / \mathrm{L}$ ) on growth, yield component and chemical content of seeds (nitrogen, phosphorus, and potassium), and fresh leaves content of chlorophyll a and b as well as seed content of fixed oil of black cumin (Nigella sativa) were investigated under sandy soil conditions. A split plot design was used where nitrogen levels were randomly arranged in main plots and the potassium silicate spray rates were randomly distributed in the sub plots, Drip irrigation was used. Distance between lines was $50 \mathrm{~cm}$ and between plants in the same row was $30 \mathrm{~cm}$ (28000 plant per fed). The obtained results obviously showed that the highest value of plant height, number of branches/plant, fresh and dry weights of herb, number of capsules for each plant, number of seeds/capsule, seed yield, weight of 1000 seeds, seed content of $\mathrm{N}, \mathrm{P}, \mathrm{K}$, leaves chlorophyll content ( $\mathrm{a}$ and $\mathrm{b}$ ) and seed fixed oil percentage were increased as $\mathrm{N}$ application level increased up to $100 \mathrm{~kg} \mathrm{~N} / \mathrm{fed}$ alone or $8 \mathrm{ml} / \mathrm{L}$ potassium silicate spray alone. The interaction results indicated that the highest value of all previous traits was recorded with plants fertilized with $100 \mathrm{~kg} \mathrm{~N} / \mathrm{fed}$ with $8 \mathrm{ml} / \mathrm{L}$ potassium silicate as foliar spray.
\end{abstract}

Key words: Nigella sativa, nitrogen, fertilization, potassium silicate, foliar spray.

\section{INTRODUCTION}

Black cumin (Nigella sativa L.) is an annual herbaceous plant belongs to family Ranunculaceae. It is widely cultivated throughout South Europe, Syria, Egypt, Saudi Arabia, Iran, Pakistan, India and Turkey (Nadeem et al., 2013). Mature seeds are consumed for edible purposes as seasoning for vegetables, legumes and different types of baked products (Hammo, 2008).

Black cumin seeds and their extracts contain anti-biotic, antihistaminic, antihypertensive, anti-inflammatory, anti- microbial, antitumor, galactagogue and insect repellent properties (Shirmohammadi et al., 2014). Also, it has been widely used as liver tonics, diuretics, digestive, antidiarrheal, appetite stimulant, analgesics, and in skin disorders (Khalid and Shedeed, 2015).

Nitrogen is vital in protein structure as well as being an active constituent of RNA and DNA, which are essential for protein synthesis (Marschner, 1995). It is also vital for NR activity which is the enzyme presential for $\mathrm{N}$ metabolism and responsible for the reduction of nitrate to ammoniacal $\mathrm{N}$, then amino acids (Hopkins, 1995). 
Nitrogen $(\mathrm{N})$ is the single which most important growth limiting factor for crops and has proved to be most instrumental among all major elements in boosting the yield of numerous plants. The success of $\mathrm{N}$ fertilization mainly arises from the indispensability of $\mathrm{N}$ as a plant nutrient, where in it forms an integral part of biologically critical molecules, such as nucleic acids, structural and catalytic protein (Shah, 2008). Agricultural soils are often deficient in $\mathrm{N}$ and hence, to ensure adequate $\mathrm{N}$ supply to crops and to prevent from nutrient deficiencies, large amounts of inorganic $\mathrm{N}$ are applied (Ali et al., 2015).

Potassium silicate is a source of highly soluble potassium and silicon. It is used in agricultural production systems primarily as a silica amendment and has the added benefit of supplying small amounts of potassium (Abou-Baker et al., 2011).

Silicon ( $\mathrm{Si}$ ) is not considered an essential plant nutrient; however, several plant species demonstrate improved disease resistance, abiotic stress tolerance, and altered morphological traits (Mattson and Leatherwood, 2010). Silicon plays an important role in growth improvement, photosynthesis increase, efficiency of transpiration and evaporation, increasing the strength of leaves, chlorophyll concentration per leaf area and product quality (Talebi et al., 2015).

So, the objective of this work was to study the effect of nitrogen fertilizer as soil application or potassium silicate foliar spray application each alone and their interaction treatments on Nigella sativa L. plant in sandy soil at EL-Arish region, North Sinai.

\section{MATERIALS AND METHODS}

This study was carried out at the Experimental Farm of Faculty of Environ. Agric. Sci., Arish University, North Sinai Governorate, Egypt, during the two successive winter seasons of 2014/2015 and $2015 / 2016$. The main object of this work was to study the effect of soil application with different $\mathrm{N}$ levels and potassium silicate foliar spray rates on the vegetative growth, fixed oil yield and some chemical constituents of Nigella sativa L. plant.

The seeds of Nigella sativa L. were obtained from Medicinal and Aromatic Plant Department, Agriculture Research Center, Cairo. The seeds were sown in sandy soil on $16^{\text {th }}$ November in both seasons. Drip irrigation system was used. Physical and chemical analyses of soil and chemical analysis of well water used for irrigation were carried out using Atomic Absorption Spectrophotometer according to Page (1982) and presented in Table 1.

This experiment included 16 treatments which were the combination between four nitrogen levels and four rates of potassium silicate foliar spray. Treatments were arranged in a split plot design with three replicates, where nitrogen fertilization levels were randomly arranged in the main plots and potassium silicate spray rates were randomly arranged in the sub plots.

Nitrogen fertilizer was applied at the levels of $0,50,75$ or $100 \mathrm{~kg} \mathrm{~N} /$ fed in the form of ammonium nitrate $(33.5 \% \mathrm{~N})$. The amount of chemical was divided into two equal doses, the first dose was applied at 60 days and the remainder at 75 days after sowing.

Foliar sprayed with potassium silicate $\left(25 \% \mathrm{SiO}_{2}+10 \% \mathrm{~K}_{2} \mathrm{O}\right)$ solution was at rates of 4,6 or $8 \mathrm{ml} / \mathrm{L}$ added in two equal doses; the first portion was after two months from sowing and the remainder at 75 days later. potassium silicate foliar spray was obtained from Abo-Ghaneima Fertilizers and Chemical Industries Company, Cairo, Egypt.

The field was properly ploughed, 3 days later it was split for lines, trenches on inside the lines were made to add compost at the rate of 15 ton/fed, ordinary supper phosphate 
Table (1): Mechanical and chemical analyses of soil and chemical analysis of well water.

\begin{tabular}{|c|c|c|c|}
\hline \multirow[b]{2}{*}{ Properties } & \multicolumn{2}{|c|}{ Soil } & \multirow[b]{2}{*}{ Well Water } \\
\hline & $\begin{array}{c}1^{\text {st }} \text { season } \\
(2014 / 2015)\end{array}$ & $\begin{array}{c}2^{\text {nd }} \text { season } \\
(2015 / 2016) \\
\end{array}$ & \\
\hline Mechanical analysis & \multicolumn{3}{|c|}{$\begin{array}{l}\text { Particular size distribution (\%) } \\
\end{array}$} \\
\hline Clay & 1.80 & 1.60 & - \\
\hline Silt & 3.10 & 3.40 & - \\
\hline Fine sand & 76.30 & 76.20 & - \\
\hline Coarse sand & 18.80 & 18.80 & - \\
\hline Soil texture & Sandy soil & Sandy soil & - \\
\hline Chemical analysis & \multicolumn{3}{|c|}{ Soluble ions (meq..$\left.^{-1}\right)$ (soil past extract) } \\
\hline $\mathrm{Ca}^{++}$ & 3.03 & 2.10 & 18.10 \\
\hline $\mathrm{Mg}^{++}$ & 2.11 & 2.20 & 20.18 \\
\hline $\mathrm{Na}^{+}$ & 1.18 & 4.49 & 17.70 \\
\hline $\mathbf{K}^{+}$ & 0.48 & 0.31 & 0.24 \\
\hline $\mathrm{Cl}^{-}$ & 1.02 & 2.30 & 38.38 \\
\hline $\mathrm{Co}_{3}^{--}$ & - & - & - \\
\hline $\mathrm{HCo}_{3}^{-}$ & 2.00 & 2.40 & 6.23 \\
\hline $\mathrm{So}_{4}^{--}$ & 3.78 & 4.40 & 11.61 \\
\hline $\mathrm{EC}\left(\mathrm{dsm}^{-1}\right)$ & 0.68 & 0.91 & 5.62 \\
\hline pH (1:2.5)soil suspensions & 8.10 & 8.20 & 6.69 \\
\hline Organic carbon $\left(\right.$ g.kg $\left.{ }^{-1}\right)$ & 0.93 & 1.22 & - \\
\hline Organic matter $\left({\mathrm{g} . \mathrm{kg}^{-1}}^{\prime}\right)$ & 1.16 & 2.10 & - \\
\hline $\mathrm{Ca} \mathrm{CO}_{3}\left(\mathrm{~g} \cdot \mathrm{kg}^{-1}\right)$ & 3.95 & 3.95 & - \\
\hline
\end{tabular}

$\left(15.5 \% \quad \mathrm{P}_{2} \mathrm{O}_{5}\right)$ and potassium sulphate $\left(48 \% \mathrm{k} 2 \mathrm{o} \mathrm{k}_{2} \mathrm{O}\right)$ at the rate of 200 and $75 \mathrm{~kg}$. fed-1 respectively, then leveled the ground, installation of irrigation hoses and plots were prepared according to the plan of layout.

The seeds had been sown in rows spaced at $30 \mathrm{~cm}$ after sowing; the seeds have been covered by soil and slightly pressed by hand and had been thinned to one plant in the hill after three weeks later. The experimental unit area was $15 \mathrm{~m}^{2}$. . Every unit contained three dripper lines with $10 \mathrm{~m}$ length. The distance between lines was 50 $\mathrm{cm}$ and between plants in the same line was $30 \mathrm{~cm}$ (28000 plant per fed). Control plots were cultivated in the same way.

Harvesting turned into began while the capsules turn yellow and the seeds in the capsules turned to black. Harvesting was manually performed in the morning. Collecting of capsules was done in paper bags on $20^{\text {th }}$ April and finished on $3^{\text {th }}$ May and open in capsules was manually opened for extraction of seeds.

Data were recorded for the plant height $(\mathrm{cm})$, number of branches /plant, herb fresh and dry weights, number of capsules, seed yield, and weight of 1000 seeds per plant. Ten plants were randomly selected from each plot and the observations were recorded.

Chlorophyll a, b contents in the fresh leaves of Nigella sativa were determined in leaf samples (mg/g fresh matter) according to Sumanta et al. (2014). Also, nitrogen and phosphorus were determined in seeds according to the standard AOAC. Procedures (1975). Potassium was determined using a flame photometer 
(Jackson, 1973). Protein content of the seed was calculated by multiplying percent nitrogen content in seed with the factor 6.25 .

Fixed oil was determined according to Kara et al (2015). The seed oil content was determined as a percentage from the seed weight using the following formula:

Fixed oil $\%=($ weight of extracted oil $/$ weight of sample $) \times 100$

All collected data were analyzed with analysis of variance (ANOVA) procedure using the General Linear Models (GLMs) procedures using SAS (SAS, 2004). Differences between means were compared by using duncan multiple range test at 0.05 level (Duncan, 1955).

\section{RESULTS AND DISCUSSION}

\section{Effect of nitrogen fertilizer rates Growth, yield and its component}

The effect of $\mathrm{N}$ levels on plant characters and yield components of Nigella sativa $\mathrm{L}$ in both seasons are presented in Table 2. The results showed that nitrogen fertilizer had significant influences on all studies traits in the two growing seasons. plant height $(\mathrm{cm})$ number of branches/plant, herb fresh and dry weights, No. of capsules/plant, number of seed/capsule, number of seeds/capsules and 1000 seed weights, were increased markedly and significantly with increasing $\mathrm{N}$ level up to $100 \mathrm{~kg} /$ fed compared with control in both seasons. However there were no significant effects between treatments of 75 and $100 \mathrm{~kg} \mathrm{~N} /$ fed regarding plant height $(\mathrm{cm})$ number of capsules/plant, number of seed/capsule and seed yield/plant in the first season and number of branches, number of capsules/plan, number of seeds/plant and 1000 seed weight in the second season. These results may be due to higher doses of nitrogen application which itself increases plant growth by promoting processes such as cell division, cell enlargement, and metabolic processes (Marschner, 1995).
These results are similar with those stated by Rana et al. (2012), Tuncturk et al. (2012), Seyyedan et al. (2014) and Yimam et al. (2015) who indicated that plant height, number of branches, herb fresh ,dry weight and number of capsules/plant of black cumin plants increased with increasing nitrogen levels Also, El-Deeb et al. (1993) on Nigella sativa plants showed that nitrogen fertilization at 60 and $80 \mathrm{~kg}$ $\mathrm{N} /$ fed-1 significantly increased seed yield/ plant. Moreover, Shah and Samiullah (2007), Rana et al. (2012) and Kaheni et al. (2013) found significant effect of $\mathrm{N}$ fertilizer levels on 1000 seed weight of black cumin. On the other side Muhammad et al. (2017) found that the application of $\mathrm{N}$ at level of $30 \mathrm{~kg} / \mathrm{ha}$ had the highest plant height $(\mathrm{cm})$, No. of capsules/ plant, No. of seeds capsules and1000 seed weigh, compared to the application 60 $\mathrm{kg} / \mathrm{ha}$ in Nigella sativa plants.

\section{Chemical constituents and oil yield:}

Results presented in Table 3 show the effect of different $\mathrm{N}$ levels on $\mathrm{N}, \mathrm{P}, \mathrm{K}$, protein percentage in seed, chlorophyll a $\& b$ in leaf and seed fixed oil. These resultsindicated that $\mathrm{N}$ fertilization significantly increased $\mathrm{N}, \mathrm{P}, \mathrm{K}$, protein percentage in seeds, chlorophyll a \&b and fixed oil.

Results indicated that the highest values for each of $\mathrm{N}, \mathrm{P}, \mathrm{K}$, protein percentage in seeds, chlorophyll a \&b were obtained by application $100 \mathrm{~kg} \mathrm{~N} /$ fed followed by $75 \mathrm{~kg}$ $\mathrm{N} /$ fed without significant differences in both seasons, while the minimum values for these traits were obtained from control treatment in both seasons.

This may suggest that nitrogen plays an important role in the physiological processes leading to the synthesis of leaf pigments. These results are in agreement with those reported by Rana et al. (2012) on black cumin who found that application of $60 \mathrm{~kg} \mathrm{~N} \mathrm{ha}^{-1}$ and $120 \mathrm{~kg} \mathrm{P} \mathrm{ha}^{-1}$ recorded maximum value for $\mathrm{N}, \mathrm{P}$ and $\mathrm{K}$ percentage. 
SINAI Journal of Applied Sciences (ISSN: 2314-6079) Vol. (8) Is. (2), Aug. 2019

Table (2): Effect of nitrogen levels on vegetative growth and yield component of Nigella sativa $L$. plants during $2014 / 2015$ and $2015 / 2016$ seasons.

\begin{tabular}{|c|c|c|c|c|c|c|c|c|}
\hline $\begin{array}{l}\text { N levels } \\
\left(\text { kgfed }^{-1}\right)\end{array}$ & $\begin{array}{c}\text { Plant height } \\
\text { (cm) }\end{array}$ & $\begin{array}{c}\text { No. } \\
\text { Branches/p } \\
\text { lant }\end{array}$ & $\begin{array}{l}\text { Herb fresh } \\
\text { weight (g) }\end{array}$ & $\begin{array}{l}\text { Herb dry } \\
\text { weight (g) }\end{array}$ & $\begin{array}{l}\text { No. } \\
\text { capsules/ } \\
\text { plant }\end{array}$ & $\begin{array}{l}\text { No. seeds/ } \\
\text { capsule }\end{array}$ & $\begin{array}{l}\text { Seed yield } \\
\text { /Plant (g) }\end{array}$ & $\begin{array}{c}1000 \text { seed } \\
\text { weight } \\
\text { (g) }\end{array}$ \\
\hline \multicolumn{9}{|c|}{ First season } \\
\hline Control & $30.61^{c}$ & $6.33^{c}$ & $4.82^{d}$ & $2.04^{d}$ & $13.91^{\mathrm{c}}$ & $86.33^{c}$ & $2.27^{\mathrm{c}}$ & $1.89^{c}$ \\
\hline 50 & $32.05^{b}$ & $6.83^{b}$ & $9.35^{\mathrm{c}}$ & $3.66^{\mathrm{c}}$ & $17.00^{b}$ & $96.19^{b}$ & $3.38^{b}$ & $2.07^{b}$ \\
\hline 75 & $37.39^{\mathrm{a}}$ & $8.58^{\mathrm{a}}$ & $14.57^{b}$ & $6.11^{b}$ & $27.50^{a}$ & $95.55^{b}$ & $5.65^{a}$ & $2.15^{b}$ \\
\hline 100 & $39.98^{\mathrm{a}}$ & $9.75^{\mathrm{a}}$ & $20.37^{a}$ & $7.16^{a}$ & $27.58^{a}$ & $102.63^{a}$ & $6.71^{\mathrm{a}}$ & $2.37^{\mathrm{a}}$ \\
\hline \multicolumn{9}{|c|}{ Second season } \\
\hline Control & $31.75^{\mathrm{c}}$ & $6.58^{c}$ & $6.82^{d}$ & $2.19^{d}$ & $13.91^{\mathrm{c}}$ & $76.67^{c}$ & $2.00^{c}$ & $1.88^{b}$ \\
\hline 50 & $35.50^{b}$ & $7.50^{\mathrm{bc}}$ & $12.06^{\mathrm{c}}$ & $4.28^{c}$ & $23.41^{b}$ & $83.78^{b}$ & $4.00^{b}$ & $2.04^{a b}$ \\
\hline 75 & $36.34^{b}$ & $8.08^{a b}$ & $20.18^{b}$ & $5.72^{b}$ & $26.00^{a b}$ & $84.00^{a b}$ & $4.54^{b}$ & $2.08^{a b}$ \\
\hline 100 & $39.15^{\mathrm{a}}$ & $8.66^{a}$ & $24.70^{a}$ & $7.00^{a}$ & $28.00^{a}$ & $93.00^{a}$ & $5.86^{\mathrm{a}}$ & $2.25^{\mathrm{a}}$ \\
\hline
\end{tabular}

Means having the same letter within the same column are not significantly different according to Duncan's multiple range test at $5 \%$ level of probability.

Table 3. Effect of nitrogen levels on chemical constituents and oil yield of Nigella sativa L. seeds during 2015/2016 and 2016/2017 seasons:

\begin{tabular}{|c|c|c|c|c|c|c|c|}
\hline $\begin{array}{l}\text { N levels } \\
\left(\text { kgfed }^{-1}\right)\end{array}$ & $\begin{array}{c}\mathrm{N} \\
(\%)\end{array}$ & $\begin{array}{c}\mathbf{P} \\
(\%)\end{array}$ & $\begin{array}{c}\mathrm{K} \\
(\%)\end{array}$ & $\begin{array}{c}\text { Seed } \\
\text { Protein } \\
(\%)\end{array}$ & $\begin{array}{c}\text { Chl. a } \\
\text { (mg/g fw) }\end{array}$ & $\begin{array}{c}\text { Chl. b } \\
\text { (mg/g fw) }\end{array}$ & $\begin{array}{c}\text { Fixed } \\
\text { oil(\%) }\end{array}$ \\
\hline \multicolumn{8}{|c|}{ First season } \\
\hline Control & $2.26^{b}$ & $0.28^{b}$ & $0.96^{b}$ & $14.17^{b}$ & $6.24^{\mathrm{b}}$ & $1.43^{b}$ & $36.07^{\mathrm{c}}$ \\
\hline 50 & $2.47^{b}$ & $0.29^{a b}$ & $1.00^{a b}$ & $15.43^{b}$ & $6.56^{\mathrm{b}}$ & $1.92^{a b}$ & $36.28^{c}$ \\
\hline 75 & $3.02^{a}$ & $0.29^{a b}$ & $1.01^{\mathrm{a}}$ & $18.89^{a}$ & $6.97^{\mathrm{ab}}$ & $2.05^{a}$ & $38.13^{b}$ \\
\hline 100 & $3.28^{a}$ & $0.32^{a}$ & $1.04^{\mathrm{a}}$ & $20.54^{\mathrm{a}}$ & $7.19^{a}$ & $2.06^{a}$ & $40.17^{a}$ \\
\hline \multicolumn{8}{|c|}{ Second season } \\
\hline Control & $2.32^{\mathrm{c}}$ & $0.29^{b}$ & $0.93^{b}$ & $14.51^{\mathrm{c}}$ & $6.45^{d}$ & $1.72^{\mathrm{c}}$ & $36.26^{d}$ \\
\hline 50 & $2.50^{\mathrm{bc}}$ & $0.30^{a b}$ & $0.95^{b}$ & $15.62^{\mathrm{bc}}$ & $6.87^{\mathrm{c}}$ & $2.05^{b c}$ & $36.99^{c}$ \\
\hline 75 & $3.02^{a b}$ & $0.30^{a b}$ & $1.03^{a}$ & $18.92^{\mathrm{ab}}$ & $7.35^{b}$ & $2.32^{a b}$ & $37.90^{b}$ \\
\hline 100 & $3.20^{a}$ & $0.31^{\mathrm{a}}$ & $1.04^{a}$ & $20.11^{a}$ & $7.81^{a}$ & $2.65^{a}$ & $39.25^{a}$ \\
\hline
\end{tabular}

Means having the same letter within the same column are not significantly different according to Duncan's multiple range test at $5 \%$ level of probability. 
Also, Khalid (2013) on Anise, coriander and sweet fennel plants demonstrated that nitrogen fertilization at the level of 200kg.N.ha ${ }^{-1}$ had a higher N, P, K, content in these plants. Moreover, Al-Hatem (2018) found that the chlorophyll content in Coriandrum sativum reached the maximum values as a results of 100 kg.N.ha ${ }^{1}$ application. On the other hand Shah and Samiullah (2007) reported that the application of nitrogen levels at $(0,40,60$, $80,100 \mathrm{~kg} \mathrm{~N}^{-1}$ on black cumin plants significantly decreased the chlorophyll content in tissue.

The fixed oil percentage in seed was higher with application of $100 \mathrm{~kg} \mathrm{~N} /$ fed followed by 75 and $50 \mathrm{~kg} \mathrm{~N} / \mathrm{fed}$. While the lower value of fixed oil percentage in seed were recorded in control treatment in both seasons. These results coincided with those obtained by Aytac et al. (2017) who revealed that the highest oil yield $\left(\mathrm{kg} \mathrm{ha}^{-1}\right)$ in black cumin was obtained from the applications of $60 \mathrm{~kg} \mathrm{~N}^{-1}$. Also, Khalid and Shedeed (2015) on Nigella sativa showed that the highest fixed oil was recorded from $\mathrm{N}_{3} \mathrm{P}_{3} \mathrm{~K}_{3}$ with foliar nutrition. Moreover, Khalid (2013) reported that the application of $\mathrm{N}$ at a level of $200 \mathrm{~kg} \mathrm{ha}^{-1}$ recorded the highest fixed oil percentage for anise, coriander and sweet fennel plants. In contrary, Ashraf et al. (2005) and
Muhammad et al. (2017) observed higher oil content in Nigella sativa plants treated with $30 \mathrm{kgNha}^{-1}$ compared with 60 and 90 $\mathrm{kgNha}^{-1}$ rate.

\section{Effect of potassium silicate foliar spray Growth, yield and its component}

Results presented in Table 4 show the effect of different potassium silicate foliar spray on growth, yield and its component. Results indicate that plant height $(\mathrm{cm})$, number of branches/plant, herb fresh and dry weights/plant, number of capsules/ plant, number of seeds/capsule, seed yield/ plant and 1000 seed weight were progressively increased with increasing application rate of potassium silicate foliar spray reach maximal values by the highest rates $\left(8 \mathrm{~cm}^{3} / \mathrm{L}\right)$ with significant differences compared with control in the two seasons. This improvement may be due to the role of silicon in enhancing plant growth via promoting desirable plant physiological processes (Korndorfer and Lepsch, 2001). These results are in a harmony with those found by Hussein and Muhammed (2017) who indicated that the higher concentrations of potassium silicate increased plant height on Solanum melongena L. plant. Also, Abdelkader et al. (2016) on roselle showed an increase in plant height and number of branches due to silicon fertilization rates.

Table (4): Effect of potassium silicate foliar spray treatments on vegetative growth and yield production of Nigella sativa $\mathrm{L}$. plants during 2014/2015 and 2015/2016 seasons.

\begin{tabular}{|c|c|c|c|c|c|c|c|c|}
\hline $\begin{array}{l}\text { Parameters } \\
\text { K Silicate } \\
\text { rates }(\mathrm{mi} / \mathrm{L}))\end{array}$ & $\begin{array}{l}\text { Plant } \\
\text { height } \\
(\mathrm{cm})\end{array}$ & $\begin{array}{c}\text { No. } \\
\text { Branches/ } \\
\text { plant }\end{array}$ & $\begin{array}{c}\text { Herb fresh } \\
\text { weight (g) }\end{array}$ & $\begin{array}{c}\text { Herb dry } \\
\text { weight (g) }\end{array}$ & $\begin{array}{c}\text { No. } \\
\text { capsules/ } \\
\text { plant }\end{array}$ & $\begin{array}{l}\text { No. seeds/ } \\
\text { capsule }\end{array}$ & $\begin{array}{c}\text { Seed } \\
\text { yield } \\
\text { /Plant } \\
(\mathrm{g}) \\
\end{array}$ & $\begin{array}{c}\text { weight } \\
\text { of } 1000 \\
\text { seeds } \\
(\mathrm{g}) \\
\end{array}$ \\
\hline \multicolumn{9}{|c|}{ First season } \\
\hline Control & $30.75^{b}$ & $6.75^{c}$ & $4.72^{d}$ & $2.63^{c}$ & 15.58 & $89.33^{c}$ & $2.48^{d}$ & $1.78^{b}$ \\
\hline 4 & $32.68^{b}$ & $7.16^{\mathrm{bc}}$ & $8.92^{c}$ & $3.30^{b}$ & 18.83 & $90.63^{c}$ & $3.75^{c}$ & $2.20^{\mathrm{a}}$ \\
\hline 6 & $37.86^{a}$ & 8.50 ab & $12.93^{b}$ & $6.38^{a}$ & $24.58^{b}$ & $97.77^{b}$ & $5.17^{\mathrm{b}}$ & $2.15^{\mathrm{a}}$ \\
\hline 8 & $38.75^{a}$ & $9.08^{a}$ & $16.55^{\mathrm{a}}$ & $6.67^{a}$ & $27.00^{\mathrm{a}}$ & $102.97^{\mathrm{a}}$ & $6.51^{a}$ & $2.34^{a}$ \\
\hline \multicolumn{9}{|c|}{ Second season } \\
\hline Control & $32.30^{c}$ & $6.58^{b}$ & $7.75^{d}$ & $2.45^{c}$ & $14.83^{c}$ & $76.67^{d}$ & $2.19^{d}$ & $1.88^{b}$ \\
\hline 4 & $35.69^{b}$ & $7.91^{\mathrm{ab}}$ & $10.38^{c}$ & $4.83^{b}$ & $23.33^{b}$ & $85.11^{c}$ & $3.87^{c}$ & $1.95^{b}$ \\
\hline 6 & $36.61^{\mathrm{a}}$ & $7.91^{a}$ & $13.96^{b}$ & $5.26^{\text {ab }}$ & $26.08^{\mathrm{a}}$ & $93.00^{b}$ & $5.04^{b}$ & $2.08^{b}$ \\
\hline 8 & $38.15^{a}$ & $8.41^{a}$ & $19.67^{\mathrm{a}}$ & $6.66^{\mathrm{a}}$ & $27.08^{a}$ & $96.11^{a}$ & $6.06^{a}$ & $2.33^{a}$ \\
\hline
\end{tabular}

Means having the same letter within the same column are not significantly different according to Duncan's multiple range test at $5 \%$ level of probability. 


\section{Chemical constituents and oil yield}

Results presented in Table 5 indicate that there were significant increases on all studies parameters, except $\mathrm{N}$ content and seeds protein $(\%)$. chlorophyll a \&b in leaf and fixed oil in both seasons. Application of $8 \mathrm{~cm}^{3} / \mathrm{L}$ of potassium silicate foliar spray significantly recorded the highest value in all traits compared with control in both seasons without significant differences than $6 \mathrm{~cm} 3 \mathrm{~L}-1$ for $\mathrm{P}$ and Chlorophyll a at first seasons, $\mathrm{K}$ content and fixed oil percentage in both seasons and chlorophyll $b$ in the second season. These results are in agreement with those reported by Hussein and Muhammed (2017) on Solanum melongena who showed that higher concentrations of potassium silicate increased $\mathrm{N}, \mathrm{P}$ and $\mathrm{K}$ percentage and chlorophyll content. Also, Talebi et al. (2015) on Solanum tuberosum showed that chlorophyll $\mathrm{a}$ and $\mathrm{b}$ were increased compared to control application due to potassium silicate solution and spray. The highest value of fixed oil percentage in seed was obtained in plant treated with $8 \mathrm{~cm}^{3} / \mathrm{L}$ potassium silicate foliar spray in both seasons, while, the minimum oil percentage in seed was obtained from control treatment in both seasons. These results are in the same line with Abd El-Razik et al. (2015) who found the highest essential oil content (\%) were in chervil (Anthriscus cerefolium) plants treated with potassium silicate at 100 ppm rate.
Effect of interaction between nitrogen rates and potassium silicate foliar spray on Nigella sativa L. plant

\section{Growth, yield and its component}

Results presented in Table 6 illustrate a significant effect for interaction between nitrogen rates and potassium silicate foliar spray on all studied traits. Application of $100 \mathrm{~kg} / \mathrm{fed} \mathrm{N}$ with $8 \mathrm{~cm}^{3} / \mathrm{L}$ of potassium silicate foliar spray had the highest values of all studied traits; viz, number of branches/plant, herb fresh and dry weights, No. of capsules plant $^{-1}$, number of seeds/capsule, number of seeds capsules ${ }^{-1}$ and 1000 seed weight. Without significant differences than application of $75 \mathrm{Kg} \mathrm{N}$ with potassium silicate as foliar spray. These results are in agreement with Emara et al. (2018) and Siam et al (2018) who found that the application of NPK 125\% + K-silicate organic achieved the best plant height in cotton and rice plants, respectively. Also Daneshm and Alamdari (2014) indicated that The highest number of seeds per panicle, seed weight and seed yield were observed by $2 \mathrm{~L} / \mathrm{ha}$ application of potassium silicate and $100 \mathrm{~kg} /$ ha nitrogen rate in RICE plants. Moreover, Mohsen et al. (2016) indicated that the highest values of plant height, number of branches and fresh \& dry weights per plant were achieved in plants treated with $8 \mathrm{~m}^{3} /$ fed vermicompost combined with $15 \mathrm{~kg} / \mathrm{fed}$. potassium silicate in Marjoram plants.

Table (5): Effect of potassium silicate foliar spray treatments on chemical constituents and oil yield of Nigella sativa $\mathbf{L}$. plants during 2014/2015 and 2015/2016 seasons.

\begin{tabular}{|c|c|c|c|c|c|c|c|}
\hline $\begin{array}{l}\text { K Silicate } \\
\text { rates }(\mathrm{mi} / \mathrm{L})\end{array}$ & $\begin{array}{l}\mathbf{N} \\
\%\end{array}$ & $\begin{array}{l}\mathbf{P} \\
\%\end{array}$ & $\begin{array}{l}\mathbf{K} \\
\mathbf{0}\end{array}$ & $\begin{array}{c}\text { Seeds } \\
\text { Protein \% }\end{array}$ & Chl. A & Chl. B & $\begin{array}{l}\text { Fixed } \\
\text { Oil \% }\end{array}$ \\
\hline \multicolumn{8}{|c|}{ First Season } \\
\hline Control & $2.54^{\mathrm{a}}$ & $0.28^{b}$ & $0.85^{b}$ & $15.87^{\mathrm{a}}$ & $5.90^{c}$ & $1.58^{b}$ & $35.89^{c}$ \\
\hline 4 & $2.74^{\mathrm{a}}$ & $0.28^{b}$ & $1.05^{\mathrm{a}}$ & $17.17^{\mathrm{a}}$ & $6.54^{b}$ & $1.67^{b}$ & $37.66^{b}$ \\
\hline 6 & $2.78^{a}$ & $0.30^{a b}$ & $1.04^{\mathrm{a}}$ & $17.41^{\mathrm{a}}$ & $6.82^{b}$ & $2.00^{b}$ & $38.61^{a}$ \\
\hline 8 & $2.97^{a}$ & $0.32^{\mathrm{a}}$ & $1.08^{a}$ & $18.58^{\mathrm{a}}$ & $7.69^{\mathrm{a}}$ & $2.22^{\mathrm{a}}$ & $39.13^{a}$ \\
\hline \multicolumn{8}{|c|}{ Second Season } \\
\hline Control & $2.69^{a}$ & $0.28^{b}$ & $0.84^{\mathrm{c}}$ & $16.84^{\mathrm{a}}$ & $6.62^{c}$ & $2.01^{b}$ & $36.38^{c}$ \\
\hline 4 & $2.71^{\mathrm{a}}$ & $0.29^{b}$ & $0.98^{b}$ & $16.97^{\mathrm{a}}$ & $6.95^{b c}$ & $2.13^{a b}$ & $37.48^{b}$ \\
\hline 6 & $2.80^{a}$ & $0.29^{b}$ & $1.05^{a b}$ & $17.53^{\mathrm{a}}$ & $7.12^{b}$ & $2.23^{\mathrm{a}}$ & 38.01 ab \\
\hline 8 & $2.85^{\mathrm{a}}$ & $0.34^{\mathrm{a}}$ & $1.10^{\mathrm{a}}$ & $17.83^{a}$ & $7.78^{a}$ & $2.38^{a}$ & $38.12^{a}$ \\
\hline
\end{tabular}

Means having the same letter within the same column are not significantly different according to Duncan's multiple range test at 5\% level of probability. 
Table (6): Effect of interaction between nitrogen fertilizer levels and potassium silicate (P.S) foliar spray rates on Nigella sativa L. plant.

\begin{tabular}{|c|c|c|c|c|c|c|c|c|c|}
\hline $\begin{array}{l}\text { N rate K Silicate } \\
\mathrm{Kg} / \text { fed }^{-1} \text { mlL }^{-1} \\
\end{array}$ & Parameter & $\begin{array}{c}\text { Plant } \\
\text { height } \\
(\mathrm{cm})\end{array}$ & $\begin{array}{c}\text { No. } \\
\text { Branches } \\
\text { /plant }\end{array}$ & $\begin{array}{c}\text { Herb fresh } \\
\text { weight (g) }\end{array}$ & $\begin{array}{l}\text { Herb dry } \\
\text { weight (g) }\end{array}$ & $\begin{array}{c}\text { No. } \\
\text { capsules/ } \\
\text { plant }\end{array}$ & $\begin{array}{c}\text { No. } \\
\text { seeds/ } \\
\text { capsule }\end{array}$ & $\begin{array}{c}\text { Seed } \\
\text { yield / } \\
\text { Plant (g) }\end{array}$ & $\begin{array}{c}1000 \text { seed } \\
\text { weight } \\
\text { (g) }\end{array}$ \\
\hline & & \multicolumn{8}{|c|}{ First Season } \\
\hline \multirow{4}{*}{ Control } & Control & $28.01^{\mathrm{e}}$ & $6.01 \mathrm{e}$ & $6.12 \mathrm{i}$ & $1.16 \mathrm{f}$ & $11.00 \mathrm{~h}$ & $79.44^{\mathrm{f}}$ & $1.31 \mathrm{i}$ & $1.50^{\mathrm{g}}$ \\
\hline & 4 & $30.66^{\mathrm{cd}}$ & $6.00^{\mathrm{e}}$ & $7.70^{\mathrm{h}}$ & $1.56^{\text {ef }}$ & $13.00 \mathrm{~h}$ & $81.89 \mathrm{f}$ & $1.70^{\mathrm{hi}}$ & $1.60^{\mathrm{fg}}$ \\
\hline & 6 & $32.33^{\mathrm{cd}}$ & $6.33^{\mathrm{de}}$ & $9.12^{\mathrm{h}}$ & $2.03^{\mathrm{def}}$ & $14.66 \mathrm{gh}$ & $92.77 \mathrm{~d}$ & $2.67^{\mathrm{e}-\mathrm{h}}$ & $1.96^{\mathrm{c}-\mathrm{f}}$ \\
\hline & 8 & $34.66^{\mathrm{c}}$ & $7.33^{\text {cde }}$ & $15.36^{\mathrm{f}}$ & $3.42^{\mathrm{c}-\mathrm{f}}$ & $17.00 \mathrm{fg}$ & $91.22^{\mathrm{de}}$ & $3.10^{\text {fgh }}$ & $2.00^{\mathrm{c}-\mathrm{f}}$ \\
\hline \multirow{4}{*}{50} & Control & $28.33^{\mathrm{de}}$ & $6.33 \mathrm{de}$ & $11.25 \mathrm{~h}$ & $1.76 \mathrm{ef}$ & $12.66 \mathrm{~h}$ & $87.77^{\mathrm{e}}$ & $1.89 \mathrm{gh}$ & $1.70^{\mathrm{efg}}$ \\
\hline & 4 & $32.00^{\mathrm{cd}}$ & $6.33^{\mathrm{de}}$ & $16.29^{\mathrm{g}}$ & $3.53^{\text {cde }}$ & $14.66 \mathrm{gh}$ & $89.66 \mathrm{de}$ & $3.06^{\mathrm{fgh}}$ & $2.33^{\mathrm{abc}}$ \\
\hline & 6 & $32.56^{\mathrm{cd}}$ & $6.66^{\mathrm{cde}}$ & $19.45^{\mathrm{de}}$ & $4.22^{\mathrm{cd}}$ & $17.66 \mathrm{fg}$ & $99.89 \mathrm{c}$ & $3.53^{\mathrm{efg}}$ & $2.00^{\mathrm{c}-\mathrm{f}}$ \\
\hline & 8 & $35.33^{b c}$ & $8.00^{\mathrm{a}-\mathrm{e}}$ & $23.44^{\mathrm{c}}$ & $5.15^{\mathrm{c}}$ & $23.00 \mathrm{de}$ & $100.55^{c}$ & $5.23^{\text {cde }}$ & $2.26^{\mathrm{a}-\mathrm{d}}$ \\
\hline \multirow[t]{4}{*}{75} & Control & $29.53^{\text {cde }}$ & $7.00 \mathrm{cde}$ & $13.39 \mathrm{~g}$ & $3.29 \mathrm{c}-\mathrm{f}$ & $18.33 \mathrm{f}$ & $92.11^{\mathrm{de}}$ & $3.31 \mathrm{efg}$ & $1.96^{\mathrm{c}-\mathrm{f}}$ \\
\hline & 4 & $34.36^{\mathrm{cd}}$ & $7.66^{\mathrm{b}-\mathrm{e}}$ & $18.24^{\text {ef }}$ & $3.61^{\text {cde }}$ & $22.66 \mathrm{de}$ & $90.22 \mathrm{de}$ & $5.03^{\text {def }}$ & $2.46^{\mathrm{ab}}$ \\
\hline & 6 & $43.66^{\mathrm{a}}$ & $10.00^{\mathrm{abc}}$ & $22.45^{\mathrm{cd}}$ & $9.89^{\mathrm{a}}$ & $28.33 \mathrm{c}$ & $99.33 \mathrm{c}$ & $6.61^{\mathrm{cb}}$ & $2.35^{\mathrm{abc}}$ \\
\hline & 8 & $41.33^{\mathrm{a}}$ & $9.66^{\mathrm{a}-\mathrm{d}}$ & $28.19^{a b}$ & $7.67^{b}$ & $31.66 \mathrm{~b}$ & $107.44^{b}$ & $8.54^{b}$ & $2.51^{\mathrm{a}}$ \\
\hline \multirow[t]{4}{*}{100} & Control & $40.33^{\mathrm{ab}}$ & $8.00 \mathrm{a}-\mathrm{e}$ & $22.13 \mathrm{de}$ & $4.30 \mathrm{~cd}$ & $20.33 \mathrm{e}$ & $98.00^{c}$ & $3.71 \mathrm{efg}$ & $1.86^{\mathrm{d}-\mathrm{g}}$ \\
\hline & 4 & $33.70^{\mathrm{cd}}$ & $8.66^{\mathrm{a}-\mathrm{e}}$ & $25.46^{b c}$ & $4.51^{c}$ & $25.00 \mathrm{~d}$ & $100.78 \mathrm{c}$ & $5.19^{\mathrm{d}}$ & $2.06^{\mathrm{b}-\mathrm{e}}$ \\
\hline & 6 & $42.23^{\mathrm{a}}$ & $11.00^{\mathrm{ab}}$ & $25.71^{b c}$ & $9.40^{\mathrm{ab}}$ & $36.33 \mathrm{a}$ & $99.11 \mathrm{c}$ & $8.32^{\text {bcd }}$ & $2.31^{\mathrm{abc}}$ \\
\hline & 8 & $44.33^{\mathrm{a}}$ & $11.33^{\mathrm{a}}$ & $31.20^{\mathrm{a}}$ & $10.44^{\mathrm{a}}$ & $37.66 \mathrm{a}$ & $112.66^{\mathrm{a}}$ & $10.82^{a}$ & $2.55^{\mathrm{a}}$ \\
\hline \multirow{5}{*}{ Control } & & \multicolumn{8}{|c|}{ Second Season } \\
\hline & Control & $30.16 \mathrm{e}$ & $5.99 \mathrm{c}$ & $6.23 \mathrm{i}$ & $1.17 \mathrm{f}$ & $11.33 \mathrm{f}$ & $76.67 \mathrm{f}$ & $1.36^{\mathrm{e}}$ & $1.56^{\mathrm{c}}$ \\
\hline & 4 & $30.40 \mathrm{e}$ & $6.00 \mathrm{c}$ & $8.42 \mathrm{i}$ & $1.65 \mathrm{f}$ & $13.66 \mathrm{ef}$ & $85.11 \mathrm{e}$ & $2.24^{\mathrm{cd}}$ & $1.93^{\mathrm{bc}}$ \\
\hline & 6 & $32.46 \mathrm{de}$ & $7.33 \mathrm{abc}$ & $10.08 \mathrm{~h}$ & $2.64 \mathrm{ef}$ & 14.33 ef & $96.11 \mathrm{c}$ & $2.75^{\mathrm{c}}$ & $2.00^{\mathrm{bc}}$ \\
\hline & 8 & $34.00 \mathrm{cde}$ & $7.33 \mathrm{abc}$ & $16.56 \mathrm{~g}$ & $3.32 \mathrm{e}$ & $16.33 \mathrm{ef}$ & $93.00 \mathrm{~d}$ & $2.98^{\mathrm{c}}$ & $1.96^{\mathrm{bc}}$ \\
\hline \multirow[t]{4}{*}{50} & Control & $32.01 \mathrm{de}$ & $6.33 \mathrm{bc}$ & $8.97 \mathrm{i}$ & $1.46 \mathrm{f}$ & $13.66 \mathrm{ef}$ & $83.78 \mathrm{e}$ & $2.13^{\mathrm{d}}$ & $1.86^{\mathrm{bc}}$ \\
\hline & 4 & $34.83 \mathrm{cde}$ & $8.00 \mathrm{abc}$ & $16.84 \mathrm{~g}$ & $5.39 \mathrm{~cd}$ & $24.33 \mathrm{~d}$ & $91.67 \mathrm{de}$ & $4.37^{\mathrm{bc}}$ & $1.96^{\mathrm{bc}}$ \\
\hline & 6 & $35.16 b-e$ & $7.66 \mathrm{abc}$ & $21.94 \mathrm{ef}$ & $3.66 \mathrm{e}$ & $26.33 \mathrm{~cd}$ & $96.67 \mathrm{c}$ & $5.24^{b c}$ & $2.06^{\mathrm{bc}}$ \\
\hline & 8 & $40.00 \mathrm{ab}$ & $8.00 \mathrm{abc}$ & $23.49 \mathrm{~cd}$ & $6.60 \mathrm{bc}$ & $29.33 a-d$ & $97.89 \mathrm{bc}$ & $6.12^{b}$ & $2.13^{b c}$ \\
\hline \multirow[t]{4}{*}{75} & Control & 32.34de & $6.33 \mathrm{bc}$ & $16.80 \mathrm{gh}$ & $3.97 \mathrm{de}$ & $15.33 \mathrm{ef}$ & $84.00 \mathrm{e}$ & $2.65^{\mathrm{cd}}$ & $2.06^{\mathrm{bc}}$ \\
\hline & 4 & $37.20 \mathrm{a}-\mathrm{d}$ & $9.00 \mathrm{a}$ & $24.09 \mathrm{de}$ & $5.63 \mathrm{c}$ & $27.33 \mathrm{bcd}$ & $96.66 \mathrm{c}$ & $5.36^{b}$ & $2.03^{b c}$ \\
\hline & 6 & $38.16 \mathrm{abc}$ & $8.00 \mathrm{abc}$ & $28.78 \mathrm{c}$ & $6.89 b c$ & $31.66 \mathrm{abc}$ & $99.33 \mathrm{bc}$ & $6.60^{b}$ & $2.10^{\mathrm{bc}}$ \\
\hline & 8 & $37.66 \mathrm{abc}$ & $9.00 \mathrm{a}$ & $32.06 \mathrm{~b}$ & $6.40 \mathrm{bc}$ & $29.66 a-d$ & $103.33 \mathrm{ab}$ & $6.83^{b}$ & $2.23^{b}$ \\
\hline \multirow[t]{4}{*}{100} & Control & $34.70 \mathrm{~cd}$ & $8.00 \mathrm{abc}$ & $21.99 \mathrm{fg}$ & $3.20 \mathrm{e}$ & $19.00 \mathrm{e}$ & $93.33 \mathrm{~d}$ & $3.60^{b c}$ & $2.03^{b c}$ \\
\hline & 4 & $40.33 \mathrm{ab}$ & $8.66 \mathrm{ab}$ & $22.16 \mathrm{cde}$ & $6.63 b c$ & $28.00 \mathrm{a}-\mathrm{d}$ & $100.67 \mathrm{~b}$ & $5.36^{\mathrm{b}}$ & $1.90^{\mathrm{bc}}$ \\
\hline & 6 & $40.66 \mathrm{a}$ & $8.66 \mathrm{ab}$ & $31.03 \mathrm{~b}$ & $7.86 \mathrm{~b}$ & $32.00 \mathrm{ab}$ & $100.33 \mathrm{~b}$ & $7.71^{\mathrm{ab}}$ & $2.40^{\mathrm{ab}}$ \\
\hline & 8 & $40.93 a$ & $9.33 \mathrm{a}$ & $33.60 \mathrm{a}$ & $10.33 a$ & $33.00 \mathrm{a}$ & $105.78 \mathrm{a}$ & $9.63^{\mathrm{a}}$ & $2.76^{\mathrm{a}}$ \\
\hline
\end{tabular}

Means having the same letter within the same column are not significantly different according to Duncan's multiple range test at $5 \%$ level of probability. 
Effect of interaction between nitrogen levels and potassium silicate foliar spray rates on Nigella sativa L. plant

\section{Growth, yield and its component}

Results in Table 7 show the effect of interaction between nitrogen and potassium silicate rates on chemical constituents and fixed oil yield of black cumin seed. Results show significant effects for the interaction on all studied traits, except, $\mathrm{N}$ content and nitrogen content in the second season. The highest values for each of $\mathrm{N}, \mathrm{P}$, and $\mathrm{K}$ percentages in seed, and chlorophyll a \&b in leaf were obtained with $100 \mathrm{~kg} / \mathrm{fed} \mathrm{N}$ with $8 \mathrm{~cm}^{3} / \mathrm{L}$ of potassium silicate foliar spray in both seasons without significant differences than application of $75 \mathrm{Kg} \mathrm{N}^{-1} \mathrm{fed}^{-1}$ +8 or $6 \mathrm{~cm}^{3} \mathrm{~L}^{-1}$ of $\mathrm{K}$ silicate in first season on $75 \mathrm{Kg} \mathrm{N}$ fed $^{-1}+6 \mathrm{~cm}^{3} \mathrm{~L}^{-1}$ of $\mathrm{K}$ silicate in the second season in most studied cases. In the same line Abou Basha et al. (2013) indicated that the treatment of $100 \mathrm{~kg} \mathrm{~N} / \mathrm{fed}$ $+5 \%$ potassium silicate significantly increased fresh, dry weight, chlorophyll a, $\mathrm{b}, \mathrm{N}, \mathrm{P}$ and $\mathrm{K}$ content in wheat plants. Also, in Marjoram plant Mohsen et al. (2016) observed that the highest values of N, P, K and $\mathrm{Ca}$ content were recorded with 8 $\mathrm{m}^{3} /$ fed. of vermicompost and $\mathrm{CaSiO}_{3}$ at 15 $\mathrm{kg} / \mathrm{fed}$.

The highest value of oil percentage in seed was obtained by application of 100 $\mathrm{kg} /$ fed with $8 \mathrm{~cm}^{3} / \mathrm{L}$ of potassium silicate foliar spray in both seasons in both seasons. While the lowest oil percentage in seed was obtained from control treatment in both seasons. These results are in the same line with Mohammed et al. (2018) who found that the highest values of essential oil yield were recorded by using vermicompost at a rate 3 or 4 -ton fed $^{-1}$ combined with spraying $3.75 \mathrm{mM}$ of silicon solution on leaves of Marjoram plant. Also, Mohsen et al. (2016) indicated that the application of vermicompost at the rate of $8 \mathrm{~m}^{3} / \mathrm{fed}$, combined with 15 $\mathrm{kg} /$ fed increased significantly essential oil determinations in Marjoram plant.

In conclusion, inoculation of Nigella sativa plants with $\mathrm{N}$ fertilizer at the level of $100 \mathrm{~kg} /$ fed or potassium silicate foliar spray at a rate of $8 \mathrm{~m}^{3} / \mathrm{fed}$ alone or together gave the highest plant height $(\mathrm{cm})$, number of branches/ plant, herb fresh and dry weight, number of capsules/plant, number of seeds/ capsule, seed yield/plant and 1000 seed weight, N, P, K content, protein percentage, chlorophyll $\mathrm{a} \& \mathrm{~b}$ in leaf and fixed oil percentage under sandy soil condition of El-Arish region.

\section{REFERENCES}

AbdEl-Razik, T.M.; Hegazy, M.H.; Amer, H.M.; Wahba, H.E.; Hendawy, S.F. and Hussein, M.S. (2015). Effect of potassium silicate as anti-transpiration on growth, essential oil of chervil plant under Egyptian conditions. Int. J. Pharm. Tech. Res., 8 (10): 32-39.

Abdelkader, M.A.; Ibrahim, M.A. and Burras, L.C. (2016). Effect of silicon application on roselle (Hibiscus sabdariffa L.) grown in a Vertisol in Egypt. J. Soil Sci. and Environ. Manag., 7 (4): 45-52.

Abou Basha, D.M.; El-Sayed, S.A.A. and El-Aila, H.I. (2013). Effect of nitrogen levels, diatomite and potassium silicate application on yield and chemical composition of Wheat (Triticum sativum L.) plants. World Appl. Sci. J., 25 (8): 1217-1221.

Abou-Baker, N.H.; Abd-Elhadl, M. and Abbas, M.M. (2011). Use of silicate and different cultivation practices in alleviating salt stress effect on bean plants. Aust. J. Basic and Appl. Sci., 5 (9): 769-781. 
Table (7): Effect of interaction between nitrogen levels and potassium silicate foliar spray rates on chemical constituents and oil yield of Nigella sativa plants during 2014/2015 and 2015/2016 season.

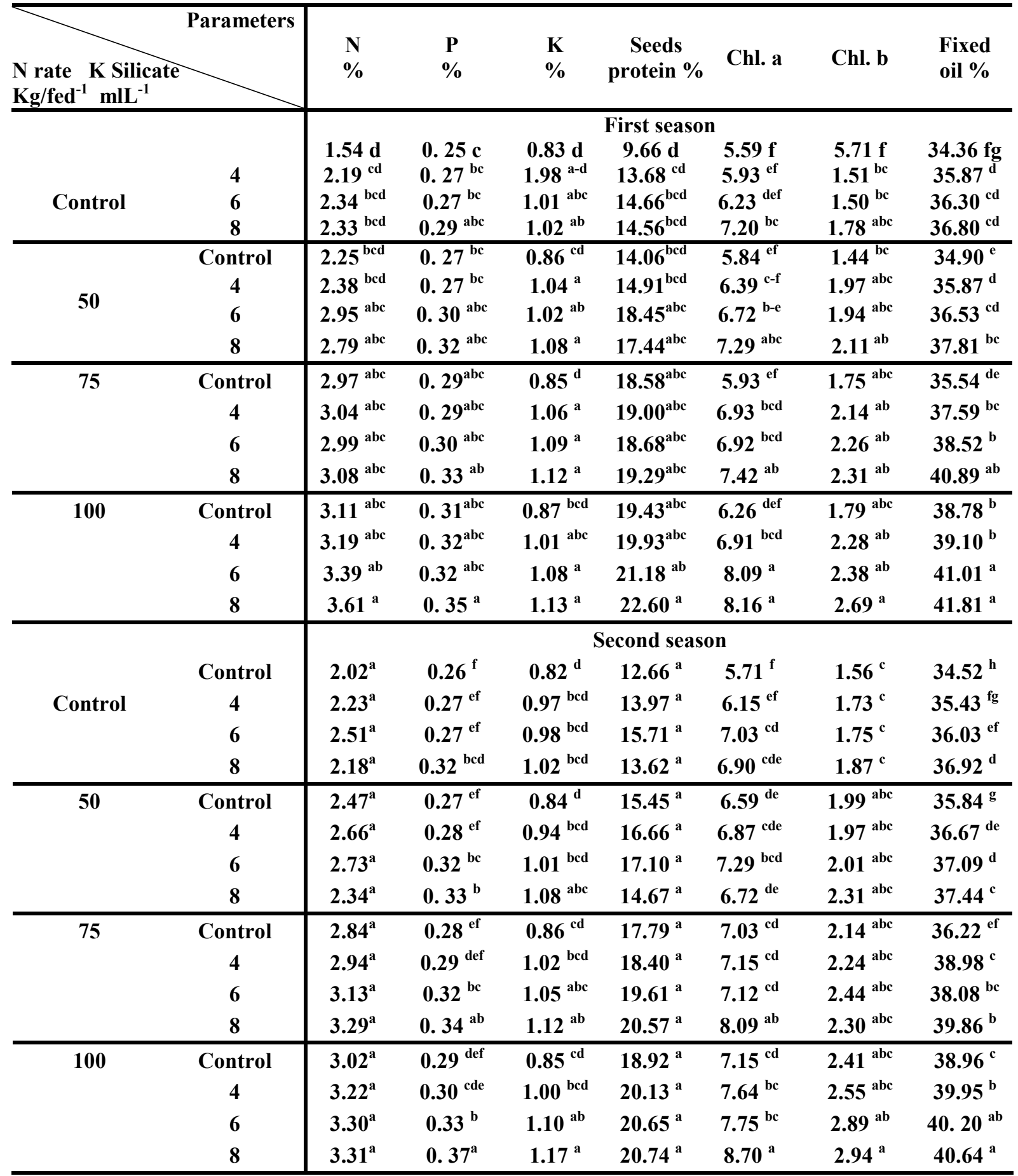

Means having the same letter within the same column are not significantly different according to Duncan's multiple range test at $5 \%$ level of probability. 
Al-Hatem, G.Y.Q. (2018). Effect of nitrogen and seaw extract (fitoalg) in some green and total yield on the plant Coriander (Coriandrum sativum L.). J. Tikrit Univ. Agri. Sci., 18(4): 72-82.

Ali, M.M.K.; Hassan, M.A. and Islam, M.R. (2015). Influence of fertilizer levels on the growth and yield of black cumin (Nigella sativa L.). A Sci. J. Krishi Foundation, 13(2): 97-104.

Ashraf, M.; Ali, Q. and Rha, E.S. (2005). The effect of applied nitrogen on the growth and nutrient concentration of Kalonji (Nigella sativa). (Electronic Version), Aust. J. Experi. Agric., 45(4): 459-463.

AOAC (1975). Association of Official Analytical Chemists. Official Methods of Analysis, $12^{\text {th }}$ Ed. Washington, D.C.

Aytac, Z.; Gulmezoglu, N.; Saglam, T.; Kulan, E.G.; Selengil, U. and Hosgun, H.L. (2017). Changes in N, K, and fatty acid composition of black cumin seeds affected by nitrogen doses under supplemental potassium application. Hindawi J. Chem., 25 (2): 141-148.

Daneshm, A. and Alamdari, G.M. (2014). Effects of different nitrogen amounts and potassium silicate foliar application on agronomic traits and seed yield of rice tarom cultivar. J. Crop Prod. Res. (Environ. Stresses In Plant Sci.), 6 (2): 107-118.

Duncan, B.D. (1955). Multipe Ranges and Multiple F test. Biomet., 11:1-42.

El-Deeb, S.; Mohamed, S.M.; ElZahawy, A.M.H. and El-Gamal, E.A. (1993). Effect of nitrogen sources and levels on the growth, seed yield and oil content of Nigella sativa plant. Egypt. J. Appl. Sci., 8 (6): 307-309.

Emara, M.A.A.; Hamoda, S.A.F. and Hamada, M.M.A. (2018). Effect of potassium silicate and NPK fertilization levels on cotton growth and productivity under different sowing dates. Egypt. J. Agron. 15 ${ }^{\text {th }}$ Ed. Int. Conf. Crop Sci., 115-123.

Hammo, Y.H. (2008). Effect of very high levels of nitrogen and phospours fertilizers, Pinching and seed rate sowing on growth, seed yield and components of Nigella sativa L. 2- seeds components. Mesopotamia J. Agric., 36 (2): ISSN 1815-316X.

Hopkins, G.W. (1995). Plants and Nitrogen. In: Introduction to Plant Physiology. John Wiley and Sons, New York, 118.

Hussein, W.A. and Muhammed, M.M. (2017). The response of white eggplant plants to foliar application with boron and potassium silicate. Assiut J. Agric. Sci., 48: 394-401.

Jackson, M.L. (1973). Soil Chemical Analysis. Prentice Hall. of India Private Limited, New Delhi.

Kaheni, A.; Ramazani, S.H.R.; Ganjali, H.R. and H.R. Mobaser (2013). Effect of nitrogen fertilizer and plant density on yield and its components in Cumin (Cuminum cyminum L.) in South Khorasan Province. Int. J. Agric. Crop Sci., 6 (5): 248-251.

Kara, N.; Katar, D. and Baydar, H. (2015). Yield and quality of black cumin (Nigella sativa L.) population the effect of ecological conditions. Turkish J. Field Crops, 20 (1): 9-14.

Khalid, K.A. and Shedeed, M.R. (2015). Effect of NPK and foliar nutrition on growth, yield and chemical constituents in Nigella sativa L. J. Mater. Environ. Sci., 6 (6): 1709-1714.

Khalid, K.A. (2013). Effect of nitrogen fertilization on morphological and biochemical traits of some apiaceae crops under arid region conditions in Egypt. Nus. Biosci. J., 5(1): 15-21. 
Korndorfer, G.H. and Lepsch, I. (2001). Effect of silicon on plant growth and crop yield. Studies in Plant Sci., 8: 133147.

Marschner, H. (1995). Mineral Nutrition of Higher Plants. $2^{\text {nd }}$ Ed. Academic Press, London, UK.

Mattson, N.S. and Leatherwood, W.R. (2010). Potassium silicate drenches increase leaf silicon content and affect morphological traits of several floriculture crops grown in a peat-based substrate. Hort. Sci., 45(1): 43-47.

Mohammed, K.A.S.; Abd El-Rheem, Kh.M.; Elsawy, A.M. and Essa, E.M. (2018). Effect of vermicompost supplemented by foliar application of silicate on Marjoram plants grown in saline soil. Int. J. Adv. Sci., Eng. and Info. Techol., 8 (4):1029-1035.

Mohsen, M.M.A.; Abo-Kora, H.A. and Kassem, A.H.M. (2016). Effect of vermicompost and calcium silicate to reduce the soil salinity on growth and oil determinations of marjoram plant. Int. J. Chem. Tech. Res., 9: 235-262.

Muhammad, A.G.; Ahmed, R.M. and Muhammed, K.E. (2017). Response of growth, yield and oil content of two Black seed species to nitrogen fertilizer in Sulaimani District. Euphrates J. Agric. Sci., 9 (4): 18-52.

Nadeem, M.A.; Tanveer, A.; Jhala, A.J. and Mubeen, K. (2013). Determining critical weed competition periods for black seed. J. Anim. and Plant Sci., 23 (1): $216-221$.

Page, A.L. (1982). Methods of Soil Analysis. Part 2: Chemical and Microbiological Properties. ( $2^{\text {nd }}$ Ed.) Ame. Soc. Agron., Int. Soil Sci. Ame. Inc., Madison, Wisconsin, USA.

Rana, S.; Singh, P.P.; Naruka, I.S. and Rathore, S.S. (2012). Effect of nitrogen and phosphorus on growth, yield and quality of black cumin (Nigella sativa L.). Int. J. Seed Spices, 2(2): 5-8.

SAS (2004). SAS/STAT User's Guide. SAS Institute Inc., Cary, N.C.

Seyyedan, P.; Daneshian, J.; Mirza, M.; Maleki, A. and Valadabadi, S.A. (2014). The effect of nitrogen chemical fertilizer and zinc sulfate application on yield and its components of Nigella sativa L. under different humidity conditions. Bull. Env. Pharmacol. Life Sci., 3 (2): 92-99.

Shah, S.H. (2008). Effects of nitrogen fertilization on nitrate reductase activity, protein, and oil yields of Nigella sativa L. as affected by foliar $\mathrm{GA}_{3}$ application. Turk J. Bot., 32: 165-170.

Shah, S.H. and Samiullah (2007). Responses of black cumin (Nigella sativa) to applied nitrogen with or without gibberellic acid spray. World J. Agri. Sci., 3(2): 153-158.

Shirmohammadi, E.; Khaje, M.; Shahgholi, H. and Talaei, G.H. (2014). Effect of biological phosphate and chemical phosphorus fertilizer on yield and yield components of Black cumin (Nigella sativa L.). Agric. Sci. Develop., 3 (9): 279-283.

Siam, S.H.; M.R. Abd El-Moez; Sh. Holah and S.T. Abou Zeid (2018) Effect of silicon addition to different fertilizer on yield of rice (Oryza sativa L.) plants. I-Macro Nutrients by Different Rice Parts. Mid. East J. Appl. Sci., 8 (1): 177-190.

Sumanta, N.; Haque, C.I.; Nishika, J. and Suprakash, R. (2014). Spectrophotometric analysis of chlorophylls and carotenoids from commonly grown fern species by using various extracting solvents. Res. J. Chem. Sci., 4(9): 63-69.

Talebi, S.; Majd, A.; Mirzai, M.; Jafari, S. and Abedini, M. (2015). The study of potassium silicate effects on qualitative and quantitative performance of potato 
(Solanum tuberosum L.). Biol. ForumAn Int. J., 7 (2): 1021-1026.

Tuncturk, R.; Tuncturk, M. and Ciftci, V. (2012). The effects of varying nitrogen doses on yield and some yield components of black cumin (Nigella Sativa L.). Adv. Enviro. Biol., 6 (2): 855-858.
Yimam, E.; Nebiyu, A.; Mohammed, A. and Getachew, M. (2015). Effect of nitrogen and phosphorus fertilizers on growth, yield and yield components of black cumin (Nigella sativa L.) at Konta District, South West Ethiopia. J. Agron., www.ansinet.com. 


\section{الملخص العربي \\ تأثير الإضافة الأرضية لمستويات النيتروجين للنيتروجين والرش بسيليكات البوتاسيوم

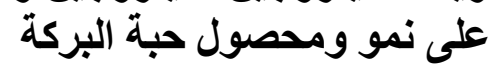

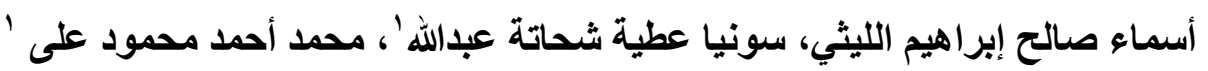

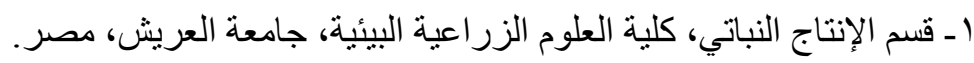

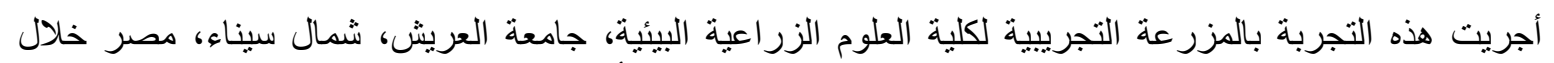

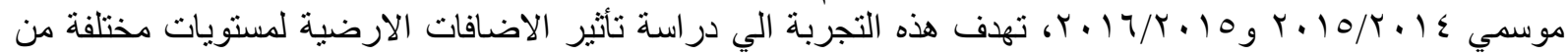

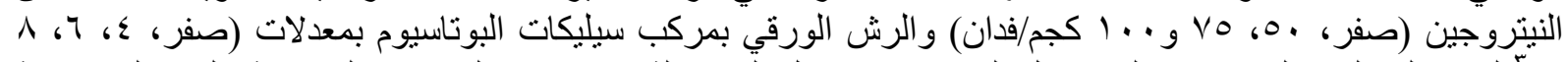

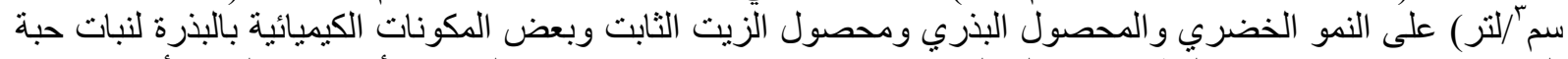

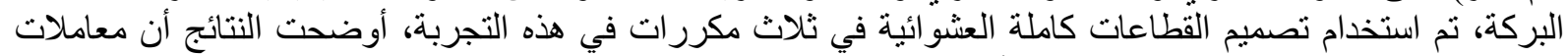

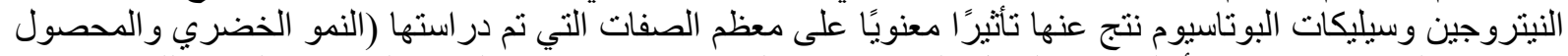

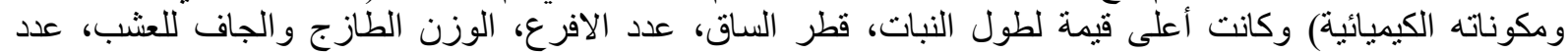

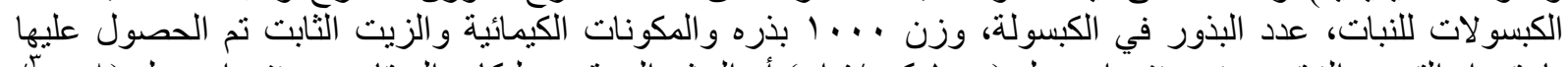

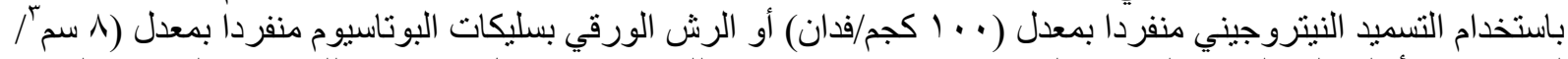

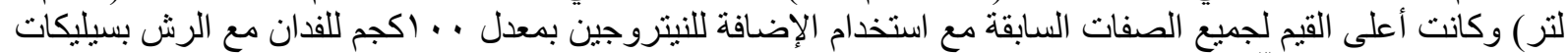

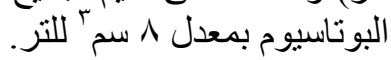

الكلمات الإسترشادية: حبة البركة، النيتروجين، التسميد، سليكات البوتاسيوم، الرش الورقي. 